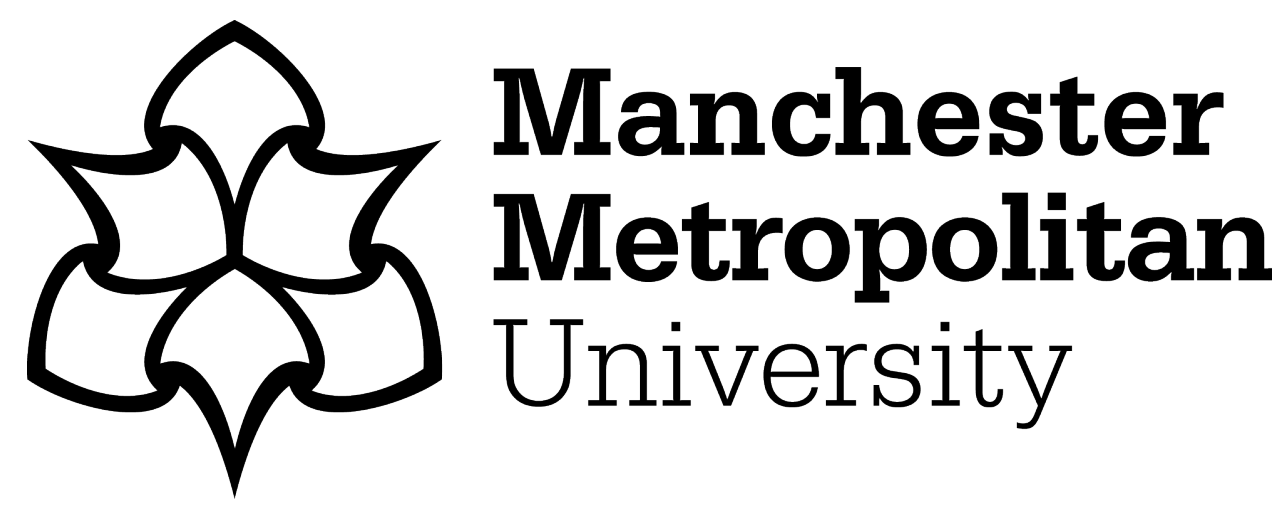

Lewin, C, Lai, KW, van Bergen, H, Charania, A, Ntebutse, JG, Quinn, B, Sherman, R and Smith, D (2018) Integrating Academic and Everyday Learning Through Technology: Issues and Challenges for Researchers, Policy Makers and Practitioners. Technology, Knowledge and Learning, 23 (3). pp. 391-407. ISSN 2211-1662

Downloaded from: https://e-space.mmu.ac.uk/621577/

Version: Accepted Version

Publisher: Springer

DOI: https://doi.org/10.1007/s10758-018-9381-0

Please cite the published version 
To cite this article: Lewin, C., Lai, K.-W., van Bergen, H., Charania, A., Ntebutse, J.G., Quinn, B., Sherman, R. \& Smith, D. (2018). Integrating academic and everyday learning through technology: Issues and challenges for researchers, policy makers and practitioners. Technology, Knowledge and Learning, 23(3), pp391-407. https://doi.org/10.1007/s10758-018-9381-0

\title{
Integrating academic and everyday learning through technology: Issues and challenges for researchers, policy makers and practitioners
}

\author{
Cathy Lewin \\ Education and Social Research Institute, Faculty of Education, Manchester \\ Metropolitan University, Brooks Building, 53 Bonsall Street, Manchester, M15 \\ $6 G X, U K$ \\ Kwok-Wing Lai \\ Centre for Distance Education and Learning Technologies, University of Otago, \\ College of Education, PO Box 56, Dunedin, New Zealand \\ Hans van Bergen \\ J3ea, Netherlands \\ Amina Charania \\ Tata Trusts \& Tata Institute of Social Sciences, V.N. Purav Marg, Deonar, \\ Mumbai 400088, India \\ Jean Gabin Ntebutse \\ Faculty of Education, University of Sherbrooke, Sherbrooke, Quebec, J1N 2Y3, \\ Canada \\ Barry Quinn \\ King's College London Dental Institute, Tower Wing, Guy's Hospital, London SE1 \\ 9RT, $U K$ \\ Roger Sherman
}


TECHNOLOGY-SUPPORTED ACADEMIC AND EVERYDAY LEARNING

\author{
Simmons School of Social Work, 300 The Fenway \\ Boston, Massachusetts 02115-5898, USA \\ David Smith
}

School of Business and Information Technology, Kaplan University, USA

\author{
Corresponding author: Cathy Lewin \\ c.lewin@mmu.ac.uk \\ +44 (0) 1612475191
}

ORCID: 0000-0002-3430-4075

\begin{abstract}
This paper builds on work undertaken over a number of years by a group of international researchers with an interest in the potential of connecting academic and everyday practices and knowledge. Drawing extensively on literature and our own work, we first discuss the challenges around defining informal learning, concluding that learning is multidimensional and has varying combinations of formal and informal attributes. We then highlight the potential of technology for integrating formal and informal learning attributes and briefly provide some exemplars of good practice. We then discuss in depth the challenges and issues of this approach to supporting learning from the perspective of pedagogy, research, policy and technology. We also provide some recommendations of how these issues may be addressed. We argue that for the learner, integration of formal and informal learning attributes should be an empowering process, enabling the learner to be self-directed, creative and innovative, taking learning to a deeper level. Given the complexity of the learning ecosystem, this demands support from the teacher but also awareness and understanding from others such as parents, family, friends and community members. We present a conceptual model of such an ecosystem to help develop further discussions within and between communities of researchers, policy makers and practitioners.
\end{abstract}

Keywords Everyday learning, informal learning, academic learning, formal learning, school, technology, pedagogy,

Acknowledgements The contributions of ideas to this paper from other TWG 2 members, Hiroaki Ogata and Ferial Khaddage, are gratefully acknowledged. We are also grateful to the two anonymous reviewers who provided us with some helpful feedback on the original draft of this paper.

\title{
Running head: Technology, academic and everyday learning
}




\section{Integrating academic and everyday learning through technology: Issues and challenges for researchers, policy makers and practitioners}

\section{Introduction}

There has been an interest in the relationship between informal and formal learning practices since a call to action was made at the EDUsummIT in 2009: To better understand student technology experiences in informal learning environments, in order to inform learning in formal settings. In the 2015 EDUsummIT, one of the main foci of discussions was the challenge of how to ensure that educational institutions recognize and accredit everyday knowledge and support informal learning practices. By 2017 discussion had moved beyond a focus on the technology per se to enabling learning to seamlessly take place as and when required without any constraints and as self rather than curriculum-driven. However, such learning has yet to be widely adopted in the classroom, even though it may already occur in everyday life where in our post-modern world, knowledge and learning preferences are fluid, ever-changing and adapting (Greene, 2009). Much more work is required before we begin to consider how we might scale-up the integration of everyday and academic learning practices and knowledge in educational contexts. In EDUsummIT 2017, the TWG members (the majority of whom are authors of this paper) considered learning with technology in relation to the school ecosystem and best practices for harnessing informal learning practices and everyday knowledge. In this paper, we summarise the findings of our TWG based on the pre-Summit research and the two and a half day discussion in Borovets, Bulgaria in September 2017.

\section{What does the literature say?}

\subsection{Conceptualising and realising informal learning}

Knowles (1950) was the first researcher to introduce the term informal learning to the literature but within adult workplace learning. Numerous definitions of informal learning now exist, including the following:

- Laurillard (2009) defines informal learning in relation to young people as “... there is no teacher, no defined curriculum topic or concept, and no external assessment. The informal learner selects their own 'teacher', who may be a peer, or may not be a person; they define their own 'curriculum, as what they are interested in learning about; and they choose whether to submit to 'assessment' by others" (p. 12). 


\section{TECHNOLOGY-SUPPORTED ACADEMIC AND EVERYDAY LEARNING}

- Similarly, Davis and Eynon (2015) suggest that informal learning is "what happens outside the structures and boundaries of formal education, the topic or focus of which is determined by the person doing the learning, on their own or with others" (p. 330). Although talking about adult learning, Rogers (2014) adds to this definition stating that informal learning involves "the everyday experiences through which we learn a great deal without ever being conscious of 'learning'" (p. 18), sometimes referred to as incidental learning (Marsick et al. 2017).

- Barron (2006) sees informal and formal learning as a continuum of learning, using an ecological perspective. For her, formal and informal learning intersect and intertwine.

- Colley et al. (2003) argue that every kind of learning has elements of formality and informality. They conceptualise these attributes under four headings: purpose (intentional/unintentional), process (structure, pedagogy, support, assessment, etc.), location (including norms and structures such as timetables) and content (high stakes knowledge to leisure interests).

- Radović and Passey (2016) conceptualise the differences between formal, non-formal and informal learning through consideration of learning activities (teacher-directed, club/interest group initiated, initiated by individual or others), learning support (teacher, club/society community, parent/family/friends) and learning setting (school, club/society venue, home).

- Rogoff et al.'s review of how informal learning can be organised (2016) recommends Callanan et al.'s (2011) framework of five dimensions, suggesting that informal learning: "is non-didactic, highly collaborative, embedded in meaningful activity, and initiated by the learner's interest or choice (rather than resulting from external demands or requirements) and does not involve assessment external to the activity" (Rogoff et al. 2016, p. 389).

As noted by many, there is a lack of consensus regarding the complex, slippery concepts of formal and informal learning (Colley et al. 2003; Rogers, 2014; Sefton-Green, 2004; Sefton-Green, 2013; Werquin, 2010). One of the main issues is that it is difficult to define the boundaries between formal and informal learning. Often it depends on what is valued as knowledge and also what can be categorised within discipline frameworks and formally assessed. The potential of mobile technology to facilitate learning at anytime and anywhere can make such boundaries even more difficult to discern. Khaddage et al. (2016) argue that the difficulty of developing a shared understanding of informal learning is one barrier to the development of pedagogies that bridge different types of learning. We must also be mindful of how other stakeholders view informal learning. For example, students in higher education and their teachers broadly understand informal learning in the traditional way, as not related to formal learning, although some teachers view informal and formal as intertwined (Lai and Smith 2017). More recently, some researchers have focused instead on sites of learning across space and time including in-school and out-of-school (Erstad 2012; Rajala et al. 2016). This conceptualisation of 'learning lives' focuses on boundary crossings between different learning practices (Erstad et al. 2013; Erstad et al. 2016). 


\section{TECHNOLOGY-SUPPORTED ACADEMIC AND EVERYDAY LEARNING}

The benefits of harnessing informal learning practices in formal contexts include authenticity, greater engagement, opportunities to develop $21^{\text {st }}$ century skills and the potential to enhance learning (Banks et al. 2007; Fallik et al. 2013; Hung et al. 2012; Ito et al. 2013; Lemke et al. 2015). Schools can draw on everyday knowledge and skills held by young people, their families and the wider community (Banks et al. 2007; Erstad et al. 2013; Kumpulainen and Mikkola 2016). While formal and informal learning are terms commonly used in the literature to refer to two distinctive forms of learning, in common with Colley and colleagues (2003), we recognise that informal and formal learning attributes can be present in all kinds of learning activities. As these attributes cannot always be easily teased out, formal and informal learning should not be viewed as binary concepts. Thus, it is noted that when the terms informal and formal learning are used in this paper, to distinguish between the acquisition of everyday knowledge and academic knowledge, we acknowledge the multidimensional connections between them. For example, a teacher in facilitating academic learning may create an authentic learning activity or encourage students to seek support from knowledgeable others outside school. Nevertheless, some forms of learning, with an emphasis on informal learning attributes, whilst being extremely valuable are not yet recognized by school systems. With potential benefits including learning across time and space, and engaging with a wide range of knowledgeable others, it is essential to develop a better understanding of the interrelationship between young people's digital practices within and outside school.

Policies are being developed to formally recognise, validate and accredit the self-directed and/or incidental learning that occurs in the home, community and workplace (Werquin 2010; Yang 2015). Learning in after-school clubs can connect academic and everyday knowledge, enabling students to focus on interest-driven activities with more flexibility and without high-stakes testing yet still benefiting academic learning (Deng et al. 2016; NRC 2015; Rogoff et al. 2016). However, such learning opportunities are not commonplace for students although teachers recognise its academic value (Birdwell et al. 2015).

\subsection{The potential of technology}

Technology, such as social media and mobile devices, offers many benefits for learning such as new and more immediate ways of accessing and creating knowledge, greater social interaction, engagement anytime and anywhere, and new modes of representation (Cox 2013; Davies and Eynon 2015; Erstad and Sefton-Green 2013; Erstad et al. 2016). Technology enables young people to engage in participatory and collaborative authentic knowledge production practices that are interest-driven (Ito et al. 2013; OECD 2016).

Technology can transform the boundaries between types and sites of learning (Furlong and Davies 2012; Greenhow and Lewin 2016), and formal educational institutions are increasingly trying to harness the potential of technology for making connections to the different types of learning that 
take place (Furlong and Davies 2012; Ito et al. 2013; Rajala, et al. 2016). Technology has created new possibilities for connecting learning across sites, connecting people with shared interests, and for integrating informal and formal learning practices (Laru and Järvelä 2015). Everyday digital practices include social media, gaming, mobile learning, engaging in online communities and digital making, all of which could support teacher-initiated learning activities (Erstad et al., 2013; Sørensen et al. 2007). Uptake of social media in education remains low partly because young people have not been equipped with the skills required to use it to support academic learning (Clark et al. 2009; Dabbagh and Kitsantas 2012; Mao 2014). Similarly, it is argued that using gaming to support academic learning requires teacher support and scaffolding (Kluge 2016). Mobile technologies can support 'seamless learning' (Chan et al. 2006) across different contexts with varying degrees of support from self-direction to teacher guidance (Sharples 2015; Wong 2013). In practice, young people make limited use of mobile technologies to engage in selfdirected learning activities that support school learning without teacher guidance (Boticki et al. 2015). The common theme here is that teacher support is critical; teachers need to develop pedagogical knowledge about connecting formal and informal learning practices but this remains a significant pedagogical challenge (Khaddage et al. 2016; Lai et al. 2013; Rajala et al., 2016). Yet it is important to address it given the continuing growth in young people's digital practices and increased opportunities for learning that technology offers, and that generic digital tools do not usually provide pedagogical support (Laru and Järvelä 2015).

\section{Exemplars of innovative learning practices}

Kumpalainen and Mikkola (2016) describe hybrid learning as bridging the intersection of academic and everyday knowledge, including various different discourses, literacies and media practices, which they argue are often marginalised in school contexts, due to the lack of recognition that learning can take place anytime, anywhere, and anyhow. They also note that young people move between different sites of learning whilst "simultaneously engaging in academic learning activities" (p. 29). Finally, they suggest that tensions arise at the intersection of the academic and everyday leading to both types of practices being challenged and reshaped. To exemplify hybrid learning, Kumpulainen and Mikkola (2016) describe how primary-aged students in Finland engaged in a year-long project to develop the school musical. Students (aged 11 and 12) focused on script writing activities, with small groups taking responsibility for separate segments. Provided with netbooks and tools for collaborative writing and synchronous communication (a chat channel), the majority of the work was undertaken outside lessons, with some taking place during the weekends. The students had greater flexibility with regards to when, where and with whom they worked. The chat channel enabled them to engage in informal discourse, whilst seeking help, evaluating each other's contributions and providing feedback. This alternative online learning space enabled the students to engage in new collaborative literacy practices within and outside school. This example illustrates how this project, initiated in school to meet curriculum objectives, became a multidimensional learning process with the support of a variety of technologies that play a critical facilitating role. This example clearly illustrates the difficulties of 


\section{TECHNOLOGY-SUPPORTED ACADEMIC AND EVERYDAY LEARNING}

treating formal and informal learning as binary opposites, as it is difficult to distinguish between them. For example, projects such as this could be conducted in curriculum time with some homework and chat channels could be used in a classroom context. However, we would argue that the authenticity of this project, the degree of student autonomy and the amount of work conducted outside the scheduled lessons (for example, $70 \%$ of the script writing activity) makes this learning experience significantly different from learning activities that are largely confined to the classroom.

Boticki et al. (2015) developed a mobile learning platform for primary-aged children enabling them to spontaneously capture media, comment and share. Students received prompts, either periodically or triggered by location, to scaffold learning. Shaped by ideas of seamless learning (Chan et al. 2006), the intention was that young people would use the technology for both teacherdirected and self-initiated activities that are potentially linked to school learning. The system was used mostly when directed by the teacher, since most students had not yet reached the stage when they would self-initiate learning activities (Boticki et al. 2015). The technology in this exemplar supports learning across contexts, including students' pursuit of their own interests, but also social engagement between peers to support collaborative learning. This enables the learning process to be more complex than it might be otherwise. The system-generated provides a form of pedagogical support and teacher access enables connections to be made with academic learning objectives.

In another example of seamless learning, the Personal Inquiry project (Jones et al. 2013; Sharples et al. 2014) utilised mobile technology, including data-gathering equipment, and pedagogical scripting mediated through the technology to support science learning across multiple contexts. Students participated in projects initiated either by their teacher or by themselves, gathering authentic data from science experiments conducted at home and outdoors. In these contexts, students used a range of mobile devices and digital resources and had greater autonomy (Jones et al. 2013). Having greater control over learning including where it takes place are attributes shared with everyday learning. As with the previous exemplar, the technology played a pivotal role in supporting the approach and enabling the learning experience to have more informal attributes although it is difficult to pin these down exactly.

In further work building on the concept of seamless learning, Ogata et al. (2011) developed a system called SCROLL which was designed to record ubiquitous language learning outside the classroom through uploading photos, audio, video, text and location data. Students posed questions through the system, which their peers or the teacher could respond to. The system includes a dictionary and an automated quiz that can help consolidate learning. Teachers can access the learning logs to build links between the learning taking place in SCROLL and classroom activities designed to support the curriculum. Various studies involving undergraduate English language learners in Japan suggest a positive impact on vocabulary learning and an increase in time spent learning outside the classroom (Ogata et al. 2011). Later developments of this system incorporated a recommender system that proposes new words (recorded by other students) based on location 


\section{TECHNOLOGY-SUPPORTED ACADEMIC AND EVERYDAY LEARNING}

data and data visualisation (Mouri et al. 2016). Again, the technology is key to enabling communication, providing instant feedback and supporting teacher understanding of their learners' development and future needs. Enabling students to learn in context through engagement with real-world activities and objects offers attributes that are shared with everyday learning.

The Integrated approach to Technology in Education project (ITE) offered project-based learning within informal learning centres in rural villages in Bengal, India to bridge the learning and opportunity gaps of lower socio-economic tribal children (Lewin and Charania 2018). Under the leadership of the organization, Suchana, these informal learning centres offered laptops to firsttime computer-users, with Internet connectivity and one-to-one support from community educators to create learning artefacts. For example, students created graphical representations of jute production in India, and measured speed, distance and time in cycling and athletics, using video and spreadsheets. These topics were carefully selected by the community educators to support the school curriculum and enhance motivation. Suchana also invited local school teachers to exhibitions at which students showcased their ITE projects, providing opportunities for educators to meet parents and celebrate the children's achievements. These events also served as platforms of exchange and boundary crossing between the schools and learning centres. The adoption of ITE at the learning centres improved: student attendance and interest in school subjects; digital skills; collaboration skills; and authentic learning opportunities. In subsequent developments, teachers were supported to implement ITE projects in their schools. Thus, informal learning practices were integrated into formal contexts. Through this initiative, the schools have realized the potential of digital technologies to facilitate learning and student interest, both very difficult goals to achieve in a lower socio-economic context where even the benefits of completing formal education are unclear. This exemplifies how even simple uses of technology in a developing country can have a positive impact on learning, extending opportunities and involving the wider community and reallife projects.

Utrecht University of Applied Sciences (Hogeschool Utrecht) developed a concept of designing education (van Bergen et al. 2016) with learning viewed as a social activity. Students gain knowledge on their own, putting it to use in context with peers. Working in learning teams, they collaborate on assignments given by the teacher within a blended learning environment. In face-toface sessions on campus they present their solutions and ask questions of their peers and the teacher. Learning practices used to develop everyday knowledge are fully integrated; for example, learning teams are not limited to classmates, but through social media like Facebook and Twitter can have members from all over the world. This has shifted the balance of learning attributes in relation to the purpose (becoming more open and less-prescribed), process (drawing more substantially on peer support within more flexible structures), location (outside the institutional context), and content (drawing on a wider knowledge range). Thus, more informal learning attributes were integrated in the activities that the students engaged in (Colley, et al., 2003). This is not formal or informal learning, but a learning experience in which everyday knowledge practices such as crowd sourcing are welcomed and promoted, rather than forbidden. The learning platform 
at the university offers easy access to those social media. There are thus no boundaries, since students can involve informal learning attributes as they please.

\section{Challenges and issues}

There remain many challenges to connecting academic and everyday learning practices and knowledge through technology, relating to pedagogy, technology, policy and research (Khaddage et al. 2016; Kumpulainen and Sefton-Green 2014; Schuck et al. 2017; Wong et al. 2015).

\section{Pedagogical challenges}

- Teacher resistance to change (Chen and Bryor 2012; Weigel et al. 2009) and time constraints (Birdwell et al. 2015; Chen and Bryor 2012).

- Young people's digital practices are shaped by context and may not readily transfer across learning sites (Crook 2012). How can educators support the integration of formal and informal learning attributes to maximise learning, and facilitate connections between everyday and academic knowledge?

- When young people use technology for self-directed or incidental learning, how can educators support self-engagement, self-regulation, critical reflection and resilience so that learners continuously develop?

\section{Research challenges}

- Despite decades of debate, a lack of consensus over the definition and boundaries of formal and informal learning still exists. This is a major barrier to the development of pedagogies that connect everyday and academic learning practices and knowledge (Khaddage et al. 2016).

- Our understanding of how to integrate academic and everyday learning practices and knowledge is limited; there are relatively few models of good practice for facilitating this through technology (Merchant 2012a).

- Some have voiced concerns about the pedagogisation of everyday life (Sefton-Green and Erstad 2017) and student resistance to invasion of personal spaces (Weigel et al. 2009).

- There has been limited uptake of the different approaches increasing informal learning attributes in academic learning to date despite strong interest by both policy makers and practitioners (Khaddage et al. 2016; Lai et al. 2013; Rajala et al. 2016).

- We need to understand how to maintain inclusivity when integrating formal and informal learning attributes through technology.

\section{Policy challenges}

- Structural constraints such as accountability, high-stakes testing, subject silos, a prescriptive curriculum and risk aversion affect the flexibility required to integrate informal and formal practices, and/or make connections between everyday and academic 
knowledge (Erstad and Sefton-Green 2013; Ito et al. 2013; King et al. 2015; Adams Becker et al. 2016; Schuck et al. 2017).

- Students need to have ubiquitous access to technology but in many countries either the infrastructure is not in place (Davis and Eynon 2015) or smartphone use may be viewed as disruptive (Hsi 2007; Merchant 2012b).

- There are different cultural expectations and particularities of specific contexts. Many countries/regions do not support the recognition and accreditation of prior (everyday) learning.

\section{Technological challenges}

- While harnessing technology can provide rich and engaging opportunities for knowledge exploration and self-discovery beyond the classroom, it can equally afford the opportunity for learners to be distracted and/or remain within their comfort zone. In what ways can technology provide the structures to support students' self-engagement, selfregulation, critical reflection and resilience in self-directed learning?

- The understanding of the interrelationship between using technology in school for learning and using technology outside school for a wide range of learning activities remains limited (Cox 2013; Hung et al. 2012). Researching learning outside school as it happens is difficult (Khaddage et al. 2016). For example, how can technology be used to record out-of-school learning experiences, taking account of ethical issues? Also, we need to understand whether or not technologies are shifting the paradigm and making learning (whether self- or teacher-directed) a more social activity.

- There is a danger that social divides in relation to technology provision, technology access and engagement, and family support, could be divisive and increase the gap between those who reach their full potential and those who do not.

We will discuss a number of issues in the following sub-sections in order to advance the field.

\subsection{Pedagogical issues}

While everyday learning practices and knowledge have huge potential for augmenting schooldirected learning, teachers' lack of understanding of its importance as well as how it can extend and motivate formal learning may constrain uptake (Lai and Smith 2018). There are at least four ways that teachers may encourage and support students to engage in informal learning practices to augment the formal learning (Lai and Smith 2018):

- Increasing students' interest in their formal course to trigger self-directed learning;

- Encouraging student agency to become self-directed and independent learners who take responsibility for their learning;

- Emphasising the importance of informal learning attributes in teaching, and providing resources to foster it, including supporting students to develop new learning skills such as 


\section{TECHNOLOGY-SUPPORTED ACADEMIC AND EVERYDAY LEARNING}

collaborative knowledge building; and

- Modelling informal learning attributes in learning systems.

Teachers also need to be aware of skills they could teach students in order to enrich their informal learning practices; for example, cognitive and metacognitive skills for managing and monitoring self-directed learning (Clark et al. 2009; Dabbagh and Kitsantas 2012; Mao 2014). From the perspective of the student however, connecting informal and formal learning could be viewed as an invasion of private space. For example, some students consider social media as a personal space and they resent its use for formal learning (Lewin and Charania 2018). Thus, teachers need to consider this issue if they are to develop pedagogical strategies to connect everyday learning practices and knowledge with classroom activities.

This brings us to the key issue of assessment. It could be argued that everyday knowledge should not be assessed because by doing so it formalises the learning activity. There are also cultural tensions in some countries in relation to high-stakes testing with teachers required to prioritise preparation for formal assessment; this could act as a barrier to integrating informal and formal learning activities. One pedagogical issue is how classroom teachers can identify and accredit everyday knowledge. Given that academic learning is the tip of the learning iceberg, valuable knowledge and skills can be acquired in informal settings outside the school.

As recommended in the EDUsummIT 2017 final report (Lewin et al. 2017), we need to:

- "Identify how practitioners can share informal learning practices that have an impact on formal learning with their students;

- Identify pedagogical approaches that take account of students' self-directed learning that is relevant to the curriculum and also support students to develop self-regulation skills through informal learning;

- Develop teachers' skills and knowledge in order to support the development of their students' digital competence including technical skills; cognitive/metacognitive skills (e.g., critical reflection, making connections between all learning experiences), and when and how to share learning, as well as their understanding of the ethical issues of using digital technologies; and

- Investigate and experiment with new and innovative technologies and applications in educational contexts such as advancements in the XAPI and cmi5 standards. These new technologies can track and report on both formal and informal learning experiences, while most Learning Management Systems do not allow for this” (pp. 29-30).

\subsection{Research issues}

There are methodological issues in undertaking research on integrating formal and informal learning attributes through technology. For example, one key issue is what perspective the 


\section{TECHNOLOGY-SUPPORTED ACADEMIC AND EVERYDAY LEARNING}

researcher should adopt: a narrow pedagogical perspective or a wider one, using multiple points of view. This is closely related to the kind of data that researchers need to collect. We suggest that ethnographic studies of different contexts in which digital technologies support learning and studies that analyse the everyday and academic learning transferred across sites would be beneficial.

As recommended by the EDUsummIT 2017 final report (Lewin et al. 2017), we should:

- "Develop technologies to enable learners to capture and reuse their learning experiences (e.g., the SCROLL system in the context of language learning);

- Develop technologies to support critical thinking;

- Conduct more evidence-based studies to understand the relationship between formal and informal learning; and

- Design studies that capture rich data on student use of technology outside formal institutions (e.g., ethnographic, walkthroughs)" (p.30).

\subsection{Policy issues}

There are many key policy issues if more informal learning attributes are to be harnessed within the classroom, and they are discussed in the following sub-sections.

\subsubsection{Ensuring inclusivity}

Policy changes have to consider a holistic view of digital inequities and inequalities in education systems. Divides include technology access, levels of digital literacy or digital competence (as discussed above) and also levels of engagement, which adds a further dimension that can widen the gap between students. It is thus important to develop strategies to motivate students to engage in informal learning activities. For example, links can be made between the formal curriculum and students' personal interests to trigger more engagement in learning. Adopting authentic learning projects can make teaching and learning more meaningful and interesting. Digital technologies facilitate increased opportunities for students to share their values, beliefs, and knowledge with their peers, both locally and in other socio-cultural contexts.

\subsubsection{Moral and ethical issues}

As well as issues of inclusion, some express concerns over the 'pedagogisation of everyday life' (Sefton-Green and Erstad 2017). That is, if teachers try to draw on students' informal learning practices and everyday knowledge it may be perceived as an invasion of personal and private spaces. However, this depends on how teachers approach the integration of informal and formal learning attributes but some students may prefer clear boundaries between school and their out-ofschool digital practices such as social media use or the pursuit of personal interests. From an alternative perspective, integrating more informal learning attributes in teacher-directed learning 


\section{TECHNOLOGY-SUPPORTED ACADEMIC AND EVERYDAY LEARNING}

could be seen as government intervention or the control of schools/governments over domestic life through blurring boundaries between school and home (Stevenson 2011). Moral and ethical issues also concern cyberethics, cybersafety, and cybersecurity (Pruit-Mentle 2008). Teachers need to develop a good understanding of these issues and how they impact formal and informal learning in order to support their students (Pusey and Sadera 2011).

\subsubsection{Implications for assessment practices}

A major challenge is the continued emphasis in many countries on accountability and prescribed curricula requiring assessment policies to be changed to encourage students to develop everyday knowledge and then ascribe value to it. Initially, it is important that policy makers develop a deeper understanding of the value of informal learning practices and reconceptualize the ecological connection between informal and formal learning attributes. We know that formal assessment often drives learning activities and without it, interventions may never be truly integrated. However, both kinds of activity could feed into assessment if student understanding about a curriculum topic is enhanced. To move forward we need to clarify what we mean by technology-enhanced informal learning attributes in multidimensional school learning and what counts as valid knowledge. If the boundary is entwined with assessment then the value of everyday knowledge and learning practices may not be recognised.

\subsubsection{How can different stakeholders be mobilised to support informal learning?}

The issue is that many teachers and parents have little understanding of how informal learning attributes can impact on young people's academic knowledge. Here, it is important to share exemplars and to provide professional development for teachers. We also need to increase the awareness of different groups of people (families, friends, community members etc.) so they can provide support for the learner. Further research of what they can do to support the shift in balance of informal and formal learning attributes is urgently needed. The EDUsummIT report (Lewin et al. 2017) recommended the following areas that policy makers should target:

- "Provide teachers with professional learning and development opportunities to develop pedagogical strategies and practices that could benefit learners to engage in informal learning;

- University teacher education programs should value informal learning by integrating it into guidance on teacher-training skills.

- Target parents and students to develop a better understanding of the issues (e.g., ethical issues) relating to the connection between formal and informal learning;

- Develop policy to collect and use information about students' informal learning preferences and activities (e.g., utilising big data);

- Identify and share exemplars of different policy approaches; and

- Promote accreditation of prior learning at all levels (e.g., schools, universities)" (p.30). 


\subsection{Technological issues}

We suggest three ways in which technology could be used to integrate formal and informal learning:

- To bring everyday knowledge into the classroom (e.g., video conferencing with a community expert).

- Facilitating informal learning practices in the classroom (e.g., game-based learning, the use of social media, collaborative learning).

- Enabling learning to take place across contexts - seamless learning (Chan et al. 2006).

However, using technology to increase informal learning attributes in formal settings requires easy access to technology and fast Internet connectivity. The BYOD (Bring Your Own Device) policy practiced by many schools may be a solution. One-to-one computing benefits teaching and learning, with an improvement in student engagement, research skills, achievement, and collaboration (Bebell and Kay 2010; New South Wales Department of Education and Training 2009). However, it should be noted that there are challenges in implementing a BYOD policy. For example, there are technical challenges such as Internet connectivity and intellectual property issues that schools have to tackle (Lai 2018).

A necessary step to enable the better integration of formal and informal learning attributes is to ensure that teachers (both pre- and in-service) and their students develop digital competence (Ntebutse 2015). Calvani et al. (2009) provide a lengthy definition of digital competence illustrating its complexity and identifying three interrelated dimensions. The technological dimension concerns being able to explore and harness new technological contexts in a flexible way. The cognitive dimension involves the ability to read, select, interpret and evaluate information, accounting for its relevance and reliability. Finally, the ethical dimension outlines the ability to interact with others, constructively and with responsibility towards oneself and others. Given this complexity, we cannot take for granted that learners and teachers are already digital competent. It is also important to eliminate the myths that overestimate the digital competence of young people through their everyday digital practices (Gallardo-Echenique et al. 2015). Digital inequities reinforce pre-existing inequities at the different levels of the social ecosystem in which learning and development of learners happen (Gorski, 2009). Therefore, we must analyse digital inequalities in education by considering their roots in the broad socio-cultural context in which learners evolve, both within and beyond institutional contexts of learning (Brotcorne and Valenduc 2009; DiMaggio et al. 2004; Gudmundsdottir 2010; Ntebutse and Collin 2018). Developing digital competence within educational systems should help address questions posed by Cox (2013) in relation to informal learning: "Is the information acquired by the learner appropriate and reliable? Does the learner have the skills to discriminate between valuable resources and useful/misleading ones? Is the learner able to scaffold his or her learning experiences to be able to build a body of knowledge and profound understanding?” (p. 12). Cox's questions are becoming increasingly 
more important with the continually expanding plethora of information available through technology and the growth of phenomena such as 'fake news'.

\section{Conclusion}

Shifting the balance of informal and formal learning attributes is a complex and multifaceted issue. Taking a systemic perspective, as depicted in Figure 1, our TWG focused on three actors: the learner, the teacher, and the parent (or care-giver) together with the wider community. For the learner, integration should be an empowering process, enabling them to be self-directed, creative and innovative, taking learning to a deeper level. The teacher should recognise and facilitate this empowerment process by developing new pedagogies to enable learner agency, to increase informal learning attributes. The role of parents is not passive. Instead, they should develop a heightened awareness of the pertinence of informal learning attributes and actively support their use to develop academic learning. Alongside parents, the wider community can also play a valuable role in supporting learners to make more connections between all their learning experiences. This empowering process should take place not only in school contexts, but in the wider learning environment impacted by research, policy, pedagogy, and technology as key interplaying factors which largely determine the success of this process. We believe it is only through orchestrated and sustained efforts at the systemic level that this empowering process can be enhanced.

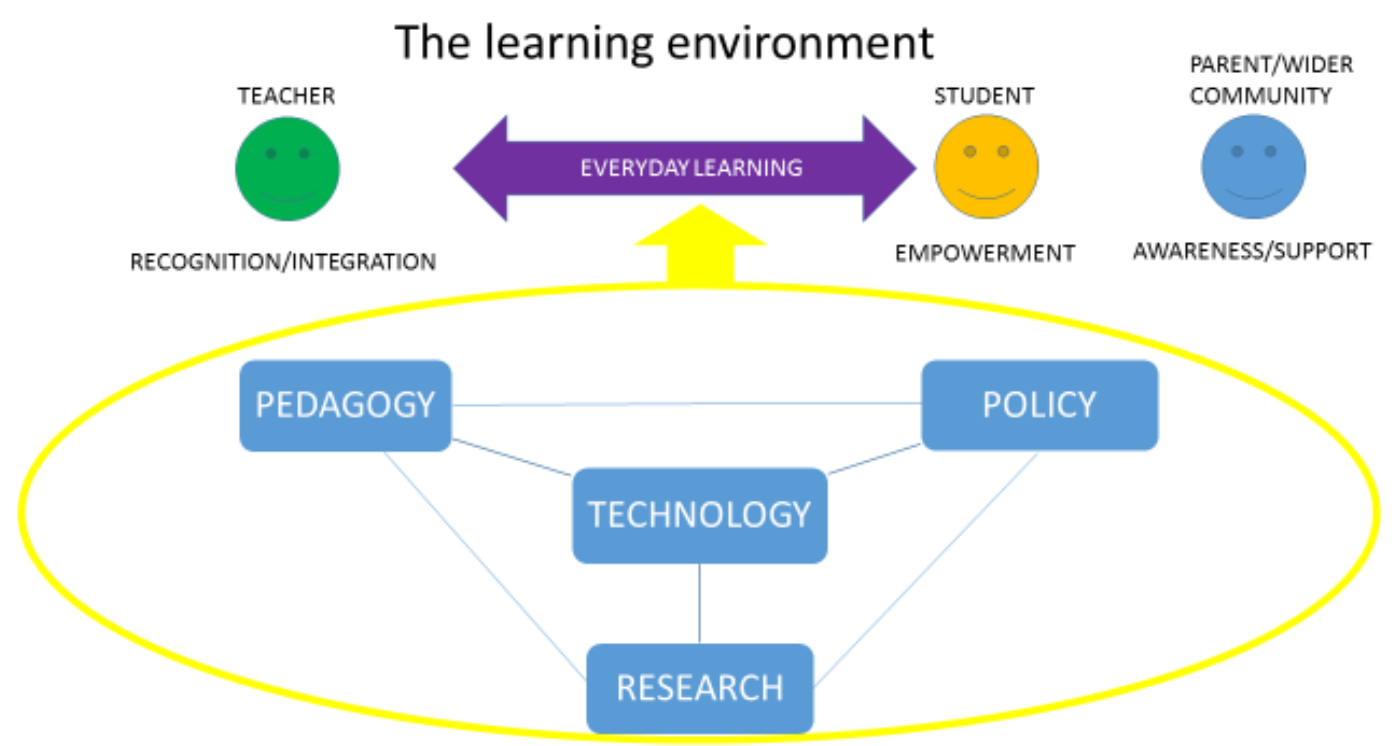

Figure 1. A systemic perspective on the integration of everyday knowledge and practices in academic learning

In this paper, we have reported the research findings of our Thematic Working Group based on a literature review and synthesis, as well as online and face-to-face discussions over a six-month 


\section{TECHNOLOGY-SUPPORTED ACADEMIC AND EVERYDAY LEARNING}

period. We have identified the key pedagogical, research, policy, and technology challenges in integrating informal and formal learning practices and increasing the integration of informal learning attributes in school-directed learning. We have discussed some of the key issues and challenges in more detail, taking the perspective of how such integration may benefit formal education (rather than considering in depth how the integration could operate in both directions). Some recommendations of how to tackle these issues are also discussed in this paper. We have proposed a preliminary conceptual model to understand the key actors and factors involved in understanding this connection. In this model we have highlighted the importance of viewing the connection between informal and formal learning attributes as an empowering process, with the learner being the central actor and the teacher, parents (or care-givers) and wider community taking a supporting and facilitating role. The interplay between the pedagogical, research, policy, and technology factors is of paramount importance in affecting the success of this connection. We suggest that conceptualizing formal and informal learning in a binary paradigm is problematic in that it does not reflect our grounded experience as educators. Rather than discrete and perhaps polar opposites, learning is viewed as multidimensional and in a postmodern fashion, fluid, ever changing and context dependent. The task is not to silo formal and informal learning but to convey the multiple levels of variables at play that craft the contextual frame and gives meaning to the learning process at a specific point in time. In future EDUsummITs, this conceptual model will be further explored and fine-tuned to understand how these factors are interconnected, and to provide a more robust tool to understand how the complexity and contribution of informal and formal learning attributes in academic learning.

\section{References}

Adams Becker, S., Freeman, A., Giesinger Hall, C., Cummins, M., \& Yuhnke, B. (2016). NMC/CoSN Horizon Report: 2016 K-12 edition. Austin, Texas: The New Media Consortium. Banks, J. A., Au, K. H., Ball, A. F., Bell, P., Gordon, E. W., Gutiérrez, K. D., \& Zhou, M. (2007). Learning in and out of school in diverse environments: Life-long, life-wide, life-deep. Seattle: LIFE Center and Center for Multicultural Education (University of Washington).

Barron, B. (2006). Interest and self-sustained learning as catalysts of development: A learning ecology perspective. Human Development, 49(4), 193-224.

Bebell, D., \& Kay, R. (2010). One to one computing: A summary of the quantitative results from the Berkshire Wireless Learning Initiative. Journal of Technology, Learning, and Assessment, 9(2). http://ejournals.bc.edu/ojs/index.php/jtla/issue/view/146. Accessed 19 January 2018.

Birdwell, J., Scott, R., \& Koninckx, D. (2015). Non-formal learning could help to build character and close attainment gap: Learning by doing. London: DEMOS.

Boticki, I., Baksa, J., Seow, P., \& Looi, C. (2015). Usage of a mobile social learning platform with virtual badges in a primary school. Computers \& Education, 86, 120-136.

Brotcorne, P., \& Valenduc, G. (2009). Les compétences numériques et les inégalités dans les usages d'internet. Comment réduire ces inégalités? Les Cahiers $d u$ numérique, 1(5), 45-68. 


\section{TECHNOLOGY-SUPPORTED ACADEMIC AND EVERYDAY LEARNING}

Callanan, M., Cervantes, C., \& Loomis, M. (2011). Informal learning. WIREs Cognitive Science, 2, 646-655.

Calvani, A., Fini, A., \& Ranieri, M. (2009). Assessing digital in secondary education. Issues, models and instruments. In M. Leaning, (Ed.), Issues in information and media literacy: education, practice and pedagogy (pp. 153-172). Santa Rosa, CA: Informing Science Press. Chan, T.-W., Roschelle, J., Hsi, S., Kinshuk, Sharples, M., Brown, T., et al. (2006). One-to-One technology-enhanced learning: An opportunity for global research collaboration. Research and Practice in Technology Enhanced Learning, 1(1), 3-29.

Chen, B., \& Bryer, T. (2012). Investigating instructional strategies for using social media in formal and informal learning. The International Review of Research in Open and Distributed Learning, 13(1): 87-104.

Clark, W., Logan, K., Luckin, R., Mee, A., \& Oliver, M. (2009). Beyond Web 2.0: Mapping the technology landscapes of young learners. Journal of Computer Assisted Learning, 25(1), 56-69.

Colley, H., Hodkinson, P., \& Malcolm, J. (2003). Informality and formality in learning: a report for the learning and skills research centre. London: Learning and Skills Research Centre.

Cox, M. J. (2013). Formal to informal learning with IT: Research challenges and issues for elearning. Journal of Computer Assisted Learning, 29(1), 1-21.

Crook, C. (2012). The 'digital native' in context: Tensions associated with importing Web 2.0 practices into the school setting. Oxford Review of Education, 38, 63-80.

Dabbagh, N., \& Kitsantas A. (2012). Personal learning environments, social media, and selfregulated learning: A natural formula for connecting formal and informal learning. Internet and Higher Education, 15(1), 3-8.

Davies, C., \& Eynon, R. (2013). Studies of the Internet in learning and education: Broadening the disciplinary landscape of research. In W. H. Dutton (Ed.), The Oxford Handbook of Internet Studies (pp. 328-349). Oxford: Oxford University Press.

Deng, L., Connelly, J., \& Lau, M. (2016). Interest-driven digital practices of secondary students: Cases of connected learning. Learning, Culture and Social Interaction, 9, 45-54.

DiMaggio, P., Hargittai, E., Celeste, E. C., \& Shafer, S. (2004). From unequal access to differentiated use: A literature review and agenda for research on digital inequality. Report prepared for the Russell Sage Foundation.

http://socinfogroup2.pbworks.com/w/file/fetch/41364119/fromunequalaccesstodifferentiateduse.pd f. Accessed 19 January 2018.

Gallardo-Echenique, E. E., Marques-Molias, L., Bullen, M., \& Strijbos, J.-W. (2015). Let's talk about digital learners. International Review of Research in Open and Distributed Learning, 16(3), 156-187.

Erstad, O., Kumpulainen, K., Mäkitalo, Å., Schrøder, K.C., Pruulmann-Vegerfeldt, P., \& Jóhannsdóttir, T. (2016). Tracing learning experiences within and across contexts: A Nordic approach. In O. Erstad, K. Kumpulainen, Å. Mäkitalo, K. C. Schrøder, P. Pruulmann-Vegerfeldt \& T. Jóhannsdóttir (Eds.), Learning across contexts in the knowledge society (pp. 1-14).

Rotterdam/Boston/Taipei: Sense Publishers. 


\section{TECHNOLOGY-SUPPORTED ACADEMIC AND EVERYDAY LEARNING}

Erstad, O. (2012). The learning lives of digital youth - Beyond the formal and informal. Oxford Review of Education, 38, 25-43.

Erstad, O., Gilje, Ø., \& Arnseth, H. C. (2013). Learning lives connected: Digital youth across school and community spaces. Comunicar, 40, 89-98.

Erstad, O., \& Sefton-Green, J. (2013). Digital disconnect? The 'Digital Learner' and the school. In O. Erstad, \& J. Sefton-Green (Eds.), Identity, community, and learning lives in the digital age (pp. 87-104.) New York: Cambridge University Press.

Fallik, O., Rosenfeld, S., \& Eylon, B. (2013). School and out-of-school science: A model for bridging the gap. Studies in Science Education, 49(1), 69-91.

Furlong, J., \& Davies, C. (2012). Young people, new technologies and learning at home: Taking context seriously. Oxford Review of Education, 38, 45-62.

Gorski, P. C. (2009). Insisting on digital equity: Reframing the dominant discourse on multicultural education and technology. Urban Education, 44(3), 348-364.

Greene, R. (2009). Human behavior theory and social work practice ( ${ }^{\text {rd }}$ edition). New Brunswick, New Jersey: Transaction Publishers.

Gudmundsdottir, G. B. (2010). From digital divide to digital equity: Learners' ICT competence in four primary schools in Cape Town, South Africa. International Journal of Education and Development using Information and Communication Technology, 6(2), 84-105.

Greenhow, C., \& Lewin, C. (2016). Social media and education: Reconceptualizing the boundaries of formal and informal learning. Learning, Media and Technology, 41(1), 6-30.

Hsi, S. (2007). Conceptualizing learning from the everyday activities of digital kids. International Journal of Science Education, 29(12), 1509-1529.

Hung, D., Lee, S. S., \& Lim, K. Y. T. (2012). Authenticity in learning for the twenty first century: Bridging the formal and the informal. Educational Technology Research \& Development, 60(6), 1071-1091.

Ito, M., Gutierrez, K., Livingstone, S., Penuel, B., Rhodes, J., Salen, K., et al. (2013). Connected learning: An agenda for research and design. Irvine, CA: Digital Media and Learning Research Hub.

Jones, A., Scanlon, E., \& Clough, G. (2013). Mobile learning: Two case studies of supporting inquiry learning in informal and semiformal settings. Computers \& Education, 61, 21-32. Khaddage, F., Christensen, R., Lai. K. W., Knezek, G., Norris, C., \& Soloway, E. (2015). A model driven framework to address challenges in a mobile learning environment. Education and Information Technologies, 20(4), 625-640.

Khaddage, F., Müller, W., \& Flintoff, K. (2016). Advancing mobile learning in formal and informal settings via mobile app technology: Where to from here, and how? Educational Technology \& Society, 19(3), 16-26.

King, H., Kersh, N., Potter, J., \& Pitts, S. (2015). Learner-led and boundary free: Learning across contexts. In J. Hohenstein, \& H. King (Eds.), Learning beyond the classroom (pp. 39-50). British Journal of Educational Psychology Monograph Series II (11). 


\section{TECHNOLOGY-SUPPORTED ACADEMIC AND EVERYDAY LEARNING}

Kluge, A. (2016). I am connected, therefore I am: Polycontextual bridging in education. In E. Elstad (Ed.), Educational technology and polycontextual bridging (pp.129-148).

Rotterdam/Boston/Taipei: Sense Publishers

Knowles, M.S. (1950). Informal adult education. New York: Association Press.

Kumpulainen, K., \& Mikkola, A. (2016). Toward hybrid learning: educational engagement and learning in the digital age. In E. Elstad (Ed.), Educational technology and polycontextual bridging (pp. 15-38). Rotterdam/Boston/Taipei: Sense Publishers.

Kumpulainen, K., \& Sefton-Green, J. (2014). What is connected learning and how to research it? International Journal of Learning and Media, 4(2), 7-18.

Lai, K. W. (2018). Learners and the digital learning processes: Research and practice in technology-enhanced learning. In J. Voogt, G. Knezek, R. Christensen, \& K. W. Lai. (Eds.), International handbook of information technology in primary and secondary education $\left(2^{\text {nd }}\right.$ edition). New York: Springer.

Lai, K. W., Khaddage, F., \& Knezek, G. (2013). Blending student technology experiences in formal and informal learning. Journal of Computer Assisted Learning, 29(5), 414-425.

Lai, K. W., \& Smith, L. A. (2017). Tertiary students' understandings and practices of informal learning: A New Zealand case study. Australasian Journal of Educational Technology, 33(2), 115 128.

Lai, K. W., \& Smith, L.A. (2018). University educators' perceptions of informal learning and the ways in which they foster it. Innovative Higher Education. Advanced online publication. DOI: $10.1007 / \mathrm{s} 10755-018-9434-2$

Lewin, C., Lai, K. W., van Bergen, H., Charania, A., Ntebutse, J. G., \& Sherman, R. (2017). Informal learning with technology. EDUsummIT summary report. In K. W. Lai, J. Voogt, \& G. Knezek (Eds.), Rethinking learning in a digital age: EDUsummIT 2017 summary report (pp. 2732). http://unesco.unibit.bg/en/EDUsummIT17 Accessed 19 January 2018.

Lewin, C., \& Charania, A. (2018). Bridging formal and informal learning through technology in the $21^{\text {st }}$ century: issues and challenges. In J. Voogt, G. Knezek, R. Christensen, \& K. W. Lai (Eds.), International handbook of information technology in primary and secondary education $\left(2^{\text {nd }}\right.$ edition). New York: Springer.

Laru, J., \& Järvelä, S. (2015). Seamless learning despite context. In L.-H. Wong, M. Specht, \& M. Milrad (Eds.), Seamless learning in the age of mobile connectivity (pp. 471-484). Singapore: Springer.

Laurillard, D. (2009). The pedagogical challenges to collaborative technologies. International Journal of Computer-Supported Collaborative Learning, 4(1), 5-20.

Lemke, J. L., Lecusay, R., Cole, M., \& Michalchik, V. (2015). Documenting and assessing learning in informal and media-rich environments. Cambridge, MA: MIT Press.

Mao, J. (2014). Social media for learning: A mixed methods study of high school students' technology affordances and perspectives. Computers in Human Behavior, 33, 213-223.

Marsick, V. J., Watkins, K. E., Scully-Russ, E., \& Nicolaides, A. (2017). Rethinking informal and incidental learning in terms of complexity and the social context. Journal of Adult Learning, 


\section{TECHNOLOGY-SUPPORTED ACADEMIC AND EVERYDAY LEARNING}

Knowledge and Innovation, 1(1). http://akademiai.com/doi/abs/10.1556/2059.01.2016.003

Accessed 19 January 2018.

Merchant, G. (2012a). Unravelling the social network: theory and research. Learning, Media and Technology, 37(1), 4-19.

Merchant, G. (2012b). Mobile practices in everyday life: popular digital technologies and schooling revisited. British Journal of Educational Technology, 43(5), 770-782.

Mouri, K., Ogata, H., Uosaki, N., \& Lkhagvasuren, E. (2016). Context-aware and personalization method based on ubiquitous learning analytics. Journal of Universal Computer Science, 22(10), pp. 1380-1397.

National Research Council (NRC) (2015). Identifying and supporting productive STEM programs in out-of-school settings. Washington, DC: The National Academies Press.

Ntebutse, J. G. (2015). Former pour le développement de la compétence numérique à l'ère des technologies numériques de type Web 2.0: Enjeux, défis et perspectives de changement. In L.

Thomas, \& M. Hirschkorn (Eds.), Change and progress in Canadian teacher education: Research on recent innovations in teacher preparation in Canada (pp. 80-107). Ottowa, ON: Canadian Association for Teacher Education.

Ntebutse, J. G., \& Collin, S. (2018). A socio-critical perspective on the integration of digital technology in education. In J.Voogt, G. Knezek, R. Christensen, \& K. W. Lai. (Eds.), International handbook of information technology in primary and secondary education $\left(2^{\text {nd }}\right.$ edition). New York: Springer.

OECD (2016). Trends shaping education 2016. Paris: OECD Publishing.

Ogata, H., Li, M., Bin, H., Uosaki, N., El-Bishoutly, M., \& Yano, Y. (2011). SCROLL:

Supporting to share and reuse ubiquitous learning logs in the context of language learning. Research and Practice on Technology Enhanced Learning, 6(3), 69-82.

Pruitt-Mentle, D. (2008). 2008 National cybersafety, cybersecurity, cyberethics baseline study. http://filecache.drivetheweb.com/mr4enh_ncsa/98/NationalC3BaselineSurvey 11_14_08_Final_w forward+\%283\%29.pdf. Accessed 19 January 2018.

Pusey, P., \& Sadera, W. A. (2011). Cyberethics, cybersafety, and cybersecurity: Preservice teacher knowledge, preparedness, and the need for teacher education to make a difference. Journal of Digital Learning in Teacher Education, 28(2), 83-88.

Radović, S., \& Passey, D. (2016). Digital resource developments for mathematics education involving homework across formal, non-formal and informal settings. The Curriculum Journal, 27(4), 538-559.

Rajala, A., Kumpulainen, K., Hilppö, J., Paananen, A., \& Lipponen, L. (2016). Connecting learning across school and out-of-school contexts: A review of pedagogical approaches. In O. Erstad, K. Kumpulainen, Å. Mäkitalo, K. C. Schrøder, P. Pruulmann-Vegerfeldt, \& T. Jóhannsdóttir (Eds.), Learning across contexts in the knowledge society (pp. 15-38).

Rotterdam/Boston/Taipei: Sense Publishers.

Rogers, A. (2014). The base of the iceberg: informal learning and its impact on formal and nonformal learning. Opladen/Berlin/Toronto: Barbara Budrich Publishers. 


\section{TECHNOLOGY-SUPPORTED ACADEMIC AND EVERYDAY LEARNING}

Rogoff, B., Callanan, M., Gutiérrez, K. D., \& Erickson, F. (2016). The organisation of informal learning. Review of Research in Education, 40, pp. 356-401.

Schuck, S., Kearney, M., \& Burden, K. (2017): Exploring mobile learning in the Third Space. Technology, Pedagogy and Education, 26(2), 121-137.

Sefton-Green, J. (2004). Report 7: Literature review in informal learning with technology outside school. Bristol, England: Futurelab.

Sefton-Green, J. (2013). Learning at Not-school: A review of study, theory, and advocacy for education in non-formal settings. Cambridge, MA: MIT Press.

Sefton-Green, J., \& Erstad, O. (2017). Researching 'learning lives' - a new agenda for learning, media and technology. Learning, Media and Technology, 42(2), 246-250.

Sharples, M. (2015). Seamless learning despite context. In L.-H. Wong, M. Milrad, \& M. Specht (Eds.), Seamless learning in the age of mobile connectivity (pp.41-55). Singapore: Springer. Sharples, M., Scanlon, E., Ainsworth, S., Anastopoulou, S., Collins, T., Crook, C., et al. (2015). Personal inquiry: Orchestrating science investigations within and beyond the classroom. Journal of the Learning Sciences, 24(2), 308-341.

Sørensen, B. H., Danielsen, O., \& Nielsen, J. (2007). Children's informal learning in the context of schools of the knowledge society. Education and Information Technologies, 12(1), 17-27. Stevenson, O. (2011). From public policy to family practices: researching the everyday realities of families' technology use at home. Journal of Computer Assisted Learning, 27(4), 336-346. The New South Wales Department of Education and Training. (2009). One-to-one computing: literature review. http://www.dec.nsw.gov.au/detresources/about-us/how-we-operate/nationalpartnerships/digital-education-revolution/rrql/support/lit_review.pdf Accessed 19 January 2018. van Bergen, H., Blauw, I., van den Bogaart, T., van de Kant, H., \& Zitter, I. (2016). Education design: A didactic concept. The Netherlands: Utrecht University of Applied Sciences.

Weigel, M., James, C., \& Gardner, H. (2009). Learning: Peering backward and looking forward in the digital era. International Journal of Learning and Media, 1(1), 1-18.

Werquin, P. (2010). Recognising non-formal and informal learning: outcomes, policies and practices. Paris, France: OECD publishing.

Wong, L.-H. (2013). Enculturating self-directed learners through a facilitated seamless learning process framework, Technology, Pedagogy and Education, 22(3), 319-338, DOI:

10.1080/1475939X.2013.778447

Wong, L.-H., Chai, C. S., Aw, G. P., \& King, R. B. (2015). Enculturating seamless language learning through artifact creation and social interaction process. Interactive Learning Environments, 23(2), 130-157. DOI: 10.1080/10494820.2015.1016534.

Yang, J. (2015). Recognition, validation and accreditation of non-formal and non-formal learning in UNESCO member states. Hamburg: UNESCO Institute for Lifelong Learning. 